\title{
CCL18 promotes epithelial-mesenchymal transition, invasion and migration of pancreatic cancer cells in pancreatic ductal adenocarcinoma
}

\author{
FANBIN MENG ${ }^{1}$, WAN $\mathrm{LI}^{2}$, CHANGLING $\mathrm{LI}^{3}$, ZHIGANG GAO ${ }^{1}$, \\ KEJIAN GUO ${ }^{1}$ and SHAOWEI SONG ${ }^{1}$
}

\begin{abstract}
Departments of ${ }^{1}$ General Surgery, Pancreatic Surgery and ${ }^{2}$ Geriatrics, The First Affiliated Hospital of China Medical University, Heping District, Shenyang 110001; ${ }^{3}$ Department of Experimental Medicine, General Hospital of Shenyang Military Area Command, Shenhe District, Shenyang 110016, P.R. China
\end{abstract}

Received September 30, 2014; Accepted November 20, 2014

DOI: 10.3892/ijo.2014.2794

\begin{abstract}
CCL18 is a chemokine that is primarily expressed in monocytes, macrophages and immature dendritic cells and plays a crucial role in immune and inflammation responses. Recently, CCL18 was found to play pivotal roles in the development of several kinds of cancers, but its expression status and role during the tumorigenesis of pancreatic cancer remain unknown. In this study, we performed immunohistochemistry and enzyme-linked immunosorbent assay (ELISA) to evaluate the expression of CCL18 in human pancreatic ductal adenocarcinoma (PDAC) tissues and preoperative serum, respectively. The results showed that both cancer epithelial cells and mesenchymal macrophages in PDAC tissues positively expressed CCL18. Serum CCL18 levels were significantly higher in patients with PDAC in comparison to healthy controls. The expression of CCL18 in both cancer epithelial cells and mesenchymal cells was correlated with lymph node metastasis, histopathological grading and overall survival in 62 PDAC patients. In vitro assays showed that the gene and protein expression of CCL18 from U937 and THP-1 cell- derived macrophages were significantly higher than that from unstimulated U937 cells and THP-1 cells. In contrast, pancreatic cancer cell lines showed little to no CCL18 expression even after IL4 stimulation. Intriguingly, pancreatic cancer cell lines expressed the potential CCL18 receptors PITPNM3, CCR6 and GPR3. Furthermore, treatment with recombinant human CCL18 promoted the migration and invasion of pancreatic cancer cells, but had no effect on cell proliferation.
\end{abstract}

Correspondence to: Professor Shaowei Song, Department of General Surgery, Pancreatic Surgery, The First Affiliated Hospital of China Medical University, 155 North Nanjing Street, Heping District, Shenyang 110001, P.R. China

E-mail: songswcmu@hotmail.com

Key words: CCL18, pancreatic cancer, epithelial-mesenchymal transition, migration, invasion
Consistent with these results, CCL18 induced the expression of the epithelial-mesenchymal transition (EMT) related gene SNAIL1. Our findings suggest that the serum level of CCL18 is a potential biomarker for the diagnosis and prognosis of PDAC, and that the combined functions of CCL18 in mesenchymal and cancer cells might accelerate the progression of PDAC by promoting the epithelial-mesenchymal transition, invasion and migration of pancreatic cancer cells.

\section{Introduction}

Pancreatic ductal adenocarcinoma (PDAC) is one of the most lethal solid tumors and is the fourth leading cause of cancerrelated death in the United States. (1) The poor prognosis of pancreatic cancer mainly results from its rapid growth, invasion and early metastasis $(2,3)$. Considerable effort has been made to treat pancreatic cancer, however, no satisfactory progress has been made during the past several years. Therefore, increased understanding of the cancer biology of pancreatic cancer and identification of novel therapeutic strategies are both urgently needed.

In addition to the extreme malignancy of the cancer epithelial cells, another hallmark of PDAC is a dense stroma surrounding the cancer cells. The stroma of PDAC is mainly composed of collagen fibers, extracellular matrix proteins, fibroblasts and inflammatory cells. An abundant extracellular matrix defends the cancer cells and is a leading cause of the enhanced malignant potential (4). It is now widely believed that the tumor-microenvironment plays key roles during both tumorigenesis and the anticancer drug response. To identify novel therapeutic pancreatic cancer targets, it is essential to investigate the interaction between the tumor and its microenvironment during the tumorigenesis of pancreatic cancer.

Among the factors associated with tumor-microenvironment interaction that are potential targets of anticancer therapies, members of the chemokine superfamily are promising candidates $(5,6)$. Chemokines are a superfamily of chemotactic cytokines with a crucial role in the immune and inflammation responses. Chemokines are classified into four groups based on the spacing of their first two cysteine residues: 
CXC, CC, $\mathrm{C}$ and $\mathrm{CX} 3 \mathrm{C}$ chemokines $(7,8)$. The most important function of chemokines is to regulate the chemotactic migration of leukocytes $(9,10)$. Recent studies have also revealed the pivotal role of chemokines in tumor progression $(11,12)$.

CCL18, a member of CC chemokine family, was recently found to play a pivotal role in the progression of malignant tumors. CCL18 is mainly expressed in monocytes, macrophages and immature dendritic cells (13-15). CCL18 protein attracts lymphocytes and immature dendritic cells and induces collagen deposition by fibroblasts (16). CCL18 is one of the most abundant factors that were expressed by tumor-associated macrophages (TAMs). Stimulators, such as IL4, can polarize macrophages to a phenotype of M2 and upregulate the expression of CCL18 (17). Enhanced CCL18 production has been demonstrated in tumor tissue, peripheral blood and dropsy of the serous cavity associated with several malignancies. Highly expressed CCL18 protein can suppress the maturation and recruitment of killer cells, including lymphocytes and dendritic cells, and destroy their immunocompetence (16). CCL18 can also promote the migration and invasion of cancer cells by binding them directly $(6,18)$. Recently, in pathway analysis of a genome-wide association study, Li et al (19) reported that CCL18 might be a susceptibility factor for the progression of pancreatic cancer through the Th1/Th2 immune response. Therefore, we hypothesized that CCL18 may play key roles during the progression of pancreatic cancer.

In this study, we evaluated the expression of CCL18 in human PDAC tissues by immunohistochemistry and preoperative serum by ELISA, and analyzed the correlation between CCL18 expression and the clinicopathological factors of 62 PDAC patients. Furthermore, we assessed the effects of CCL18 on the proliferation, migration and invasion of in vitro cultured pancreatic cancer cells.

\section{Materials and methods}

Patients and samples. Sixty-two patients (46 males and 16 females, median age 59 years, range 35-75), who underwent resection of PDAC at our institution between January 2007 and December 2011, were included in this study. Clinical data was collected from a pathography of the patients. The pathological classification of these cases was based on the UICC (Union for International Cancer Control)-TNM classification of malignant tumors (20). Preoperative serum was collected from 24 PDAC patients and the control group consisted of eight age- and gender-matched healthy volunteers. The use of the clinical samples was approved by the Ethics Committee of the First Affiliated Hospital of China Medical University, and written informed consent was obtained from each patient.

Cell lines and treatment. Human pancreatic cancer cell lines PANC-1, BxPC-3, CAPAN-2 and SW1990, and human monocyte cell lines U937 and THP-1 were purchased from American Type Culture Collection (ATCC, Rockville, MD, USA). Cells were grown in RPMI-1640 medium containing $10 \%$ fetal bovine serum (FBS), $100 \mathrm{U} / \mathrm{ml}$ penicillin and $100 \mu \mathrm{g} / \mathrm{ml}$ streptomycin and were incubated at $37^{\circ} \mathrm{C}$ in a $5 \% \mathrm{CO}_{2}$ atmosphere. For the collection of pancreatic cancer cells for quantitative real-time PCR (qRT-PCR) or cell culture supernatants of these cells for enzyme-linked immunosorbent assay (ELISA), the four pancreatic cancer cell lines were cultured at a density of $5 \times 10^{5} / \mathrm{ml}$. After incubation for one day, the medium was replaced by fresh medium with or without IL-4. After incubation for additional $72 \mathrm{~h}$, the supernatants and cells were collected. For the collection of macrophages for qRT-PCR or cell culture supernatant for ELISA, U937 and THP-1 cells were incubated at a density of $5 \times 10^{5} / \mathrm{ml}$ and stimulated for two days by $10 \mathrm{ng} / \mathrm{ml}$ (U937) or $100 \mathrm{ng} / \mathrm{ml}$ (THP-1) of phorbol 12-myristate 13-acetate (PMA, Sigma-Aldrich), respectively. Non-adherent cells were removed by washing and new medium with or without $45 \mathrm{ng} / \mathrm{ml} \mathrm{IL} 4$ was added. After incubation for three days, the cells and supernatants were collected. The two monocyte cell lines were incubated at a density of $5 \times 10^{5} / \mathrm{ml}$ for seven days to collect cells and the supernatant.

Immunohistochemistry and immunofluorescence. Patient PDAC tissues were formalin-fixed and paraffin-embedded. The tissue sections (3-4 $\mu \mathrm{m}$ ) were rehydrated and treated with $3 \%$ hydrogen peroxide in methanol, followed by antigen retrieval. After being blocked with Dako ${ }^{\circledR}$ Protein Block, the sections were incubated with primary antibodies at $4^{\circ} \mathrm{C}$ overnight. This was followed by incubation with a secondary antibody for $30 \mathrm{~min}$ at room temperature. Slides were then treated with streptavidin-peroxidase reagent at $37^{\circ} \mathrm{C}$ for $15 \mathrm{~min}$. For immunohistochemistry, Dako ${ }^{\circledast}$ DAB Chromogen was used for the color-reaction followed by nucleus counterstaining with hematoxylin. For immunofluorescence, the nucleus was counterstained by DAPI and imaged using a Nikon Eclipse E600 microscope with DP Manager Version 1.2.1.107 software. The following antibodies were used: primary antibodies: rabbit anti-CCL18 (1:200, Abcam); mouse anti-CD68 (1:100, Dako); mouse anti-CD163 (1:100, Novocastra); mouse anti-Ki67 (1:50, Abcam); mouse anti-p53 (1:200, Abcam), mouse anti-CEA (1:400, Abcam); mouse anti-CA19-9 (1:100, Abcam); mouse anti-CD34 (1:100, Abcam); secondary antibodies: anti-rabbit or anti-mouse $\operatorname{IgG}$ (1:200, Vector Laboratories); Alexa Fluor 594 donkey anti-rabbit or 488 goat anti-mouse $\operatorname{IgG}(\mathrm{H}+\mathrm{L})(1: 200$, Life Technologies).

$q R T-P C R$. Total RNA was extracted from pancreatic cancer cells or monocyte/macrophages using TRIzol reagent according to the instructions of the manufacturer (Takara Bio). CDNA was synthesized using GoScript ${ }^{\mathrm{TM}}$ Reverse Transcription system according to the manufacturer's instructions (Promega). The relative levels of target gene mRNA to control GAPDH were determined by qRT-PCR in a 7900 HT Fast Real-Time PCR system (Applied Biosystems) using the GoTaq ${ }^{\circledast}$ qPCR Master Mix (Promega). The data were analyzed by the $2^{-\Delta \Delta C t}$ method. The sequences are listed in Table I.

ELISA. CCL18 levels in cell culture supernatants and the serum of healthy volunteers or PDAC patients were determined quantitatively using a human PARC (CCL18) ELISA kit (Raybiotech) as described by the manufacturer.

Cell proliferation assay (MTT assay). Cells (BxPC-3, PANC-1) were seeded in 96-well plates at a density of $5 \times 10^{4} / \mathrm{ml}$ in $100 \mu \mathrm{l}$ of complete medium and grown for $24 \mathrm{~h}$. Then the medium was replaced with serum-free medium containing different concentrations of recombinant human CCL18 (rh-CCL18, 
Table I. The sequences of PCR primers used in this study.

\begin{tabular}{lllr}
\hline Gene & \multicolumn{1}{c}{ Forward primer } & \multicolumn{1}{c}{ Reverse primer } & Amplicon (bp) \\
\hline CCL18 & 5'-CTCTGCTGCCTCGTCTATACCT-3' & 5'-CTTGGTTAGGAGGATGACACCT-3' & 108 \\
PITPNM3 & 5'-GATGCCAGAGGAGAAGGGAC-3' & 5'-TCGCTGTCTTCGTGGATCTC-3' & 134 \\
CCR6 & 5'-GCTCAAGTGTTCACAACCTGGAAG-3' & 5'-TCCTAATGGCCCACTACAACCTG-3' & 118 \\
GPR3 & 5'-TCCTCTCTCTAGCCCTGCTC-3' & 5'-CTCTCTGGGTACCTGGGTTG-3' & 148 \\
SNAIL1 & 5'-CATCCTTCTCACTGCCATGGA-3' & 5'-AGGCAGAGGACACAGAACCAGA-3' & 107 \\
VEGF & 5'-ATGACGAGGGCCTGGAGTGTG-3' & 5'-CCTATGTGCTGGCCTTGGTGAG-3' & 91 \\
IL8 & 5'-AAACCACCGGAAGGAACCAT-3' & 5'-CCTTCACACAGAGCTGCAGAAA-3' & 101 \\
E-cadherin & 5'-AGTGCCAACTGGACCATTCA-3' & 5'-TCTTTGACCACCGCTCTCCT-3' & 314 \\
CD44 & 5'-TGCCGCTTTGCAGGTGTAT-3' & 5'-GGCCTCCGTCCGAGAGA-3' & 66 \\
CXCR4 & 5'-GCCTTATCCTGCCTGGTATTGTC-3' & 5'-GCGAAGAAAGCCAGGATGAGGAT-3' & 130 \\
GAPDH & 5'-TGCACCACCAACTGCTTAGC-3' & 5'-GGCATGGACTGTGGTCATGAG-3' & 87 \\
\hline
\end{tabular}

Peprotech). After incubation for 24-72 h, cell Titer 96 AQueous One Solution Cell Proliferation assay (Promega) was added (20 $\mu \mathrm{l} /$ well) and incubated for $90 \mathrm{~min}$. Finally, the optical densities (OD) were measured at $492 \mathrm{~nm}$.

Transwell chamber assay. Transwell chamber migration assay was performed using Nunc 24-well 8.0- $\mu \mathrm{m}$-pore transwell plates (Thermo Fisher Scientific) according to the manufacturer's instructions. Pancreatic cancer cells were plated into the upper chambers at $5 \times 10^{4} / \mathrm{ml}$. The lower chambers contained $5-25 \mathrm{ng} / \mathrm{ml}$ rh-CCL18 or macrophages prepared beforehand. After incubation for $24 \mathrm{~h}$, non-invading cells were removed from the upper surface of the membrane using a cotton-tipped swab. Then the invading cells were fixed in methanol for $10 \mathrm{~min}$ and stained with $0.1 \%$ crystal violet hydrate (Sigma) for $30 \mathrm{~min}$. The invading cells were counted as cells per field at 10x magnification. The invasion assay was performed in a similar fashion except the $8.0-\mu \mathrm{m}$ pore size membrane inserts were coated with matrigel (BD Biosciences) that was diluted at 1:6 with serum-free media.

Western blotting. Total proteins were extracted from cells with RIPA cell lysis buffer (Cell Signaling) on ice for $30 \mathrm{~min}$. Equal amounts of proteins were separated by $10 \%$ SDS-PAGE and transferred to polyvinylidene difluoride membranes (Millipore). The membranes were blocked with $2 \%$ fat-free milk in PBS at room temperature for $1 \mathrm{~h}$ and probed with primary anti-SNAIL1 antibody (1:500, Abcam), E-cadherin (1:500, Abcam) or $\beta$-actin $(1: 1,000$, Peproteck) antibodies at $4^{\circ} \mathrm{C}$ overnight. Membranes were incubated with peroxidaseconjugated anti-rabbit IgG secondary antibody (1:5,000, Beyotime) at room temperature for $45 \mathrm{~min}$. Immunoreactive protein bands were visualized with an ECL detection kit (Thermol Biotech). The experiment was repeated three times.

Statistical analysis. Statistical comparisons of means were performed by Student's t-test, whereas $\chi^{2}$ test was applied to analyze the relationship between CCL18 expression status and clinicopathological factors. Cutoff value of CCL18-positive macrophage counts was calculated by performing non- parametric receiver operating characteristics (ROC) using Dr. SPSS II for windows. The cutoff value was defined according to the best predictive values calculated by ROC analysis (cutoff value: 19.5 cells/40x magnification). Statistic significance was defined as $\mathrm{P}<0.05$.

\section{Results}

CCL18 is expressed in PDAC tissue. To evaluate the expression status of CCL18 in human PDAC tissues, we performed immunohistochemical analysis of CCL18 in PDAC tissues from 62 patients. Compared with normal pancreas, there was dramatically increased expression of CCL18 in PDAC tissues (Fig. 1A-E). Among all the cases tested, 61.29\% (38/62) stained positively for CCL18 in cancer cells and 70.97\% (44/62) were positive in mesenchymal cells, while $45.16 \%$ (28/62) stained positively in both cancer and mesenchymal cells. Thus, $85.48 \%$ (53/62) showed a positive expression of CCL18 in cancer and/or mesenchymal cells. Notably, in cases with positive staining in both cancer and mesenchymal cells, the staining of CCL18 in cancer epithelial cells was weaker than that in mesenchymal cells (Fig. 1D). These results demonstrated that both the cancer epithelial and mesenchymal cells of PDAC tissue positively express CCL18.

The concentration of CCL18 in the peripheral blood serum of patients with PDAC is significantly higher than that of healthy controls. Currently, several serum markers, such as CEA and CA19-9, are commonly used to detect the origin, recurrence and metastasis of pancreatic cancer $(21,22)$. Since CCL18 is a soluble protein and is upregulated in PDAC tissues, we hypothesized that serum levels of CCL18 might serve as a diagnostic or follow-up marker in PDAC. We measured the concentration of soluble CCL18 in serum samples of patients with PDAC $(n=24)$ and in healthy donors $(n=8)$ by ELISA. The serum level of CCL18 in PDAC patients was $8,913.60 \mathrm{pg} / \mathrm{ml}$ to $270,117.30 \mathrm{pg} / \mathrm{ml}(65,337.19 \pm 63,287.63 \mathrm{pg} / \mathrm{ml})$ while that of healthy donors was $3,721.57 \mathrm{pg} / \mathrm{ml}$ to $25,046.21 \mathrm{pg} / \mathrm{ml}$ $(17,510.83 \pm 8,717.47 \mathrm{pg} / \mathrm{ml})(\mathrm{P}=0.039)($ Fig. $1 \mathrm{~F})$. Moreover, $75 \%(18 / 24)$ of the PDAC samples demonstrated higher CCL18 

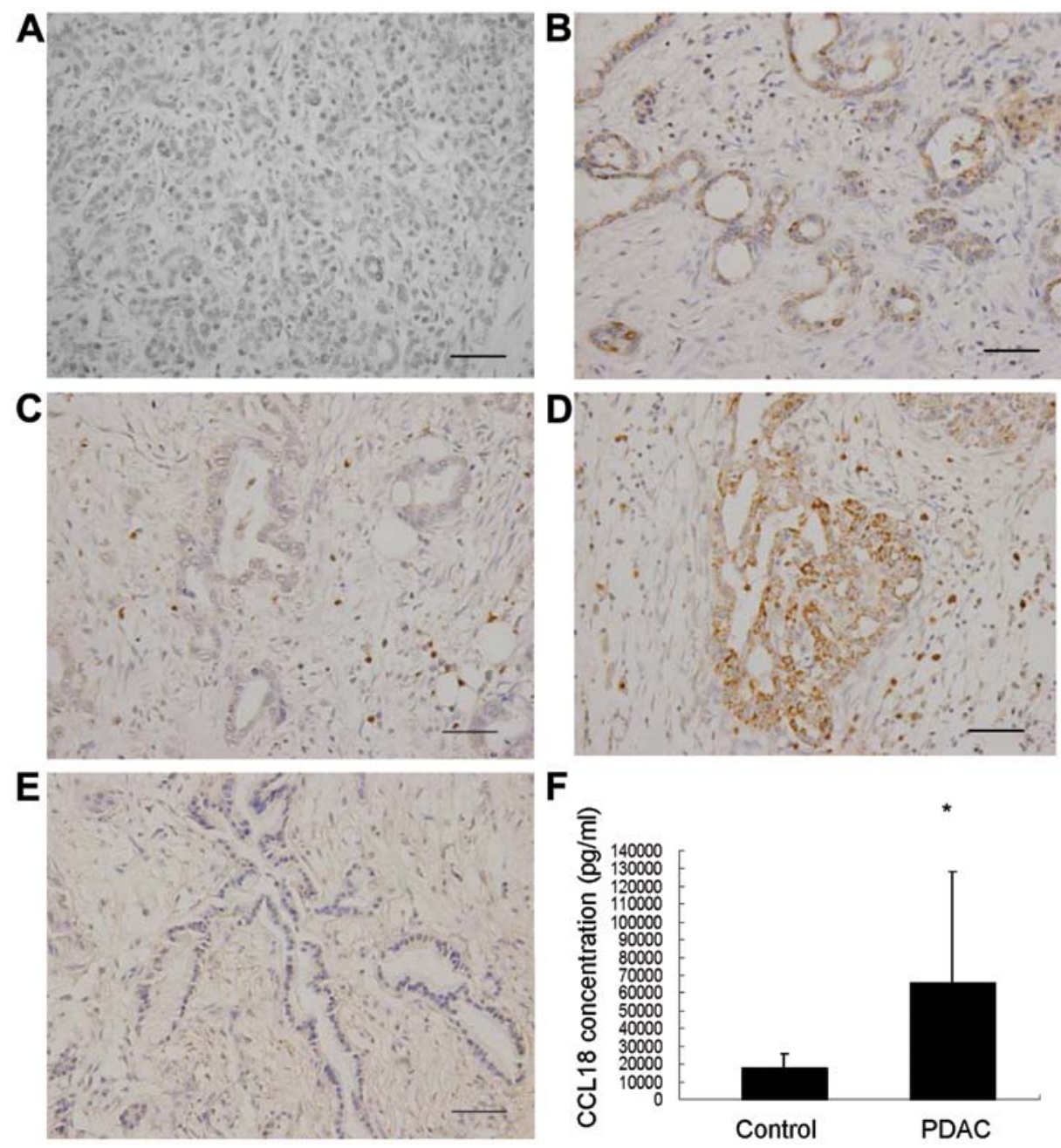

Figure 1. CCL18 is positively expressed in PDAC tissue. (A-E) Expression and localization of CCL18 in pancreatic tissues. (A) Normal pancreas; (B-E) PDAC [(B) cancer cells +/mesenchymal cells -, (C) cancer cells -/mesenchymal cells + , (D) cancer cells $+/$ mesenchymal cells + , (E) cancer cells -/mesenchymal cells -]. (F) Concentration of CCL18 in the serum of healthy controls and patients with PDAC (" $\mathrm{P}<0.05$ versus control). (A-E) Scale bar, $50 \mu \mathrm{m}$.

levels than the highest value measured in the control group. Therefore, the serum CCL18 levels were significantly higher in patients with PDAC in comparison to healthy controls, suggesting that serum CCL18 level is a potentially useful biomarker for the diagnosis and prognosis of PDAC.

CCL18 expression in both cancer and mesenchymal cells correlates with PDAC tumor progression and a worse survival rate for PDAC patients. We next analyzed the correlation between the expression of CCL18 and the clinicopathological factors of 62 PDAC patients. The clinical data are summarized in Tables II and III. The results revealed that CCL18 expression in both cancer and mesenchymal cells was significantly correlated with lymph node metastasis $(\mathrm{P}=0.015)$ and UICC stage $(\mathrm{P}=0.037)$ (Table II). Moreover, the number of CCL18expressing mesenchymal cells was significantly associated with tissue CA19-9 expression level ( $\mathrm{P}=0.030)$ (Table III).

We further examined the correlation between the expression of CCL18 and the overall survival of these 62 PDAC patients by Kaplan-Meier analysis. CCL18 expression in cancer cells (Fig. 2A, $\mathrm{P}=0.311$ ), mesenchymal cells (Fig. 2B, $\mathrm{P}=0.358$ ), and the count of mesenchymal positive cells (Fig. $2 \mathrm{C}, \mathrm{P}=0.057$ ) was not statistically associated with survival of PDAC patients.
Interestingly, PDAC patients with CCL18 expression in both cancer and mesenchymal cells had a significantly worse overall survival rate than patients without CCL18 expression in either cell type (Fig. 2D, $\chi^{2}=6.165, \mathrm{P}=0.013$ ).

CCL18-positive cells in the mesenchyme of PDAC tissues are M2-polarized macrophages. Previous reports showed that CCL18 is mainly expressed in the monocyte-macrophage system and is highly expressed in tumor-associated macrophages (TAMs) (17). It is thus possible that the CCL18positive mesenchymal cells in our tested PDAC tissues are macrophages. To test this hypothesis, we performed immunofluorescence staining of both CCL18 and the macrophage marker CD68. CCL18-expressing cells co-localized with CD68 positive staining (Fig. 3A-C), indicating that CCL18expressing cells are macrophages. Moreover, in agreement with a previous report (6), additional double staining of CD163 and CCL18 indicated that CCL18-expressing macrophages were a subset of CD163-positive M2-polarized macrophages (Fig. 3D-F).

U937 and THP-1 cell derived macrophages secrete high levels of CCL18 while cultured pancreatic cancer cells 
A

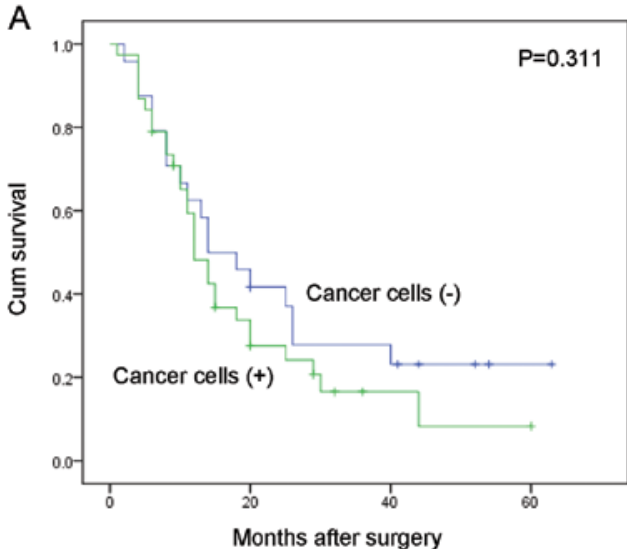

C

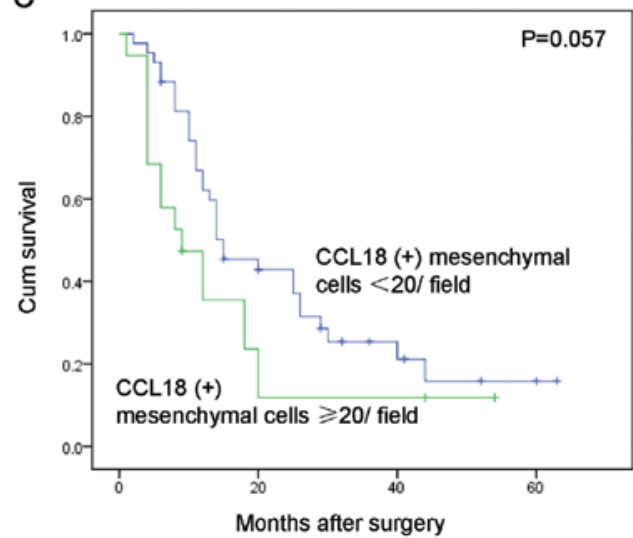

B

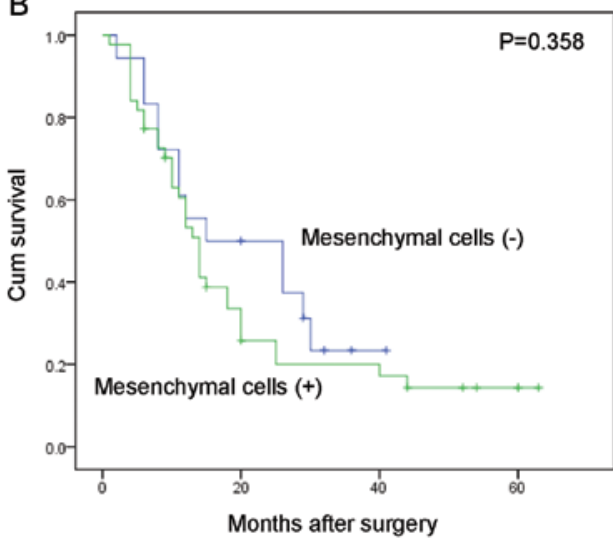

D

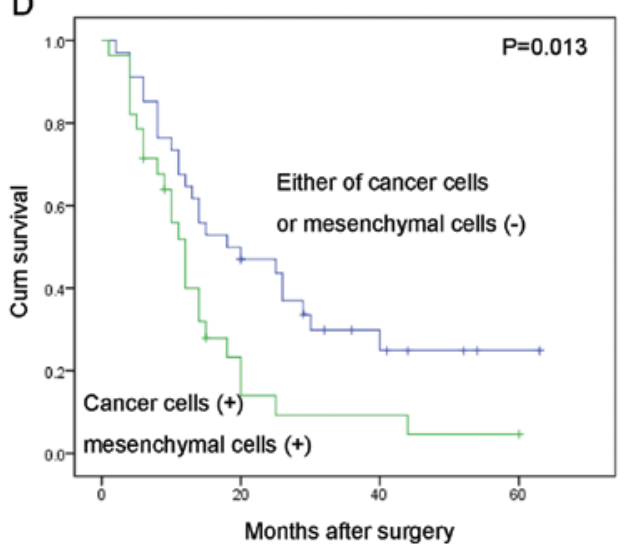

Figure 2. Kaplan-Meier analysis of overall survival of PDAC patients. Expression of CCL18 in 62 PDAC patients was plotted against the time of overall survival. (A) Cancer cells positive versus cancer cells negative expression of CCL18. (B) Mesenchymal cells positive versus mesenchymal cells negative espression of CCL18. (C) Lower (<20 per view of field) CCL18-positive cell counts versus higher CCL18-positive cell counts ( $\geq 20$ per view of field). (D) CCL18-positive expression in both cancer and mesenchymal cells versus CCL18-negative expression in either cell types.
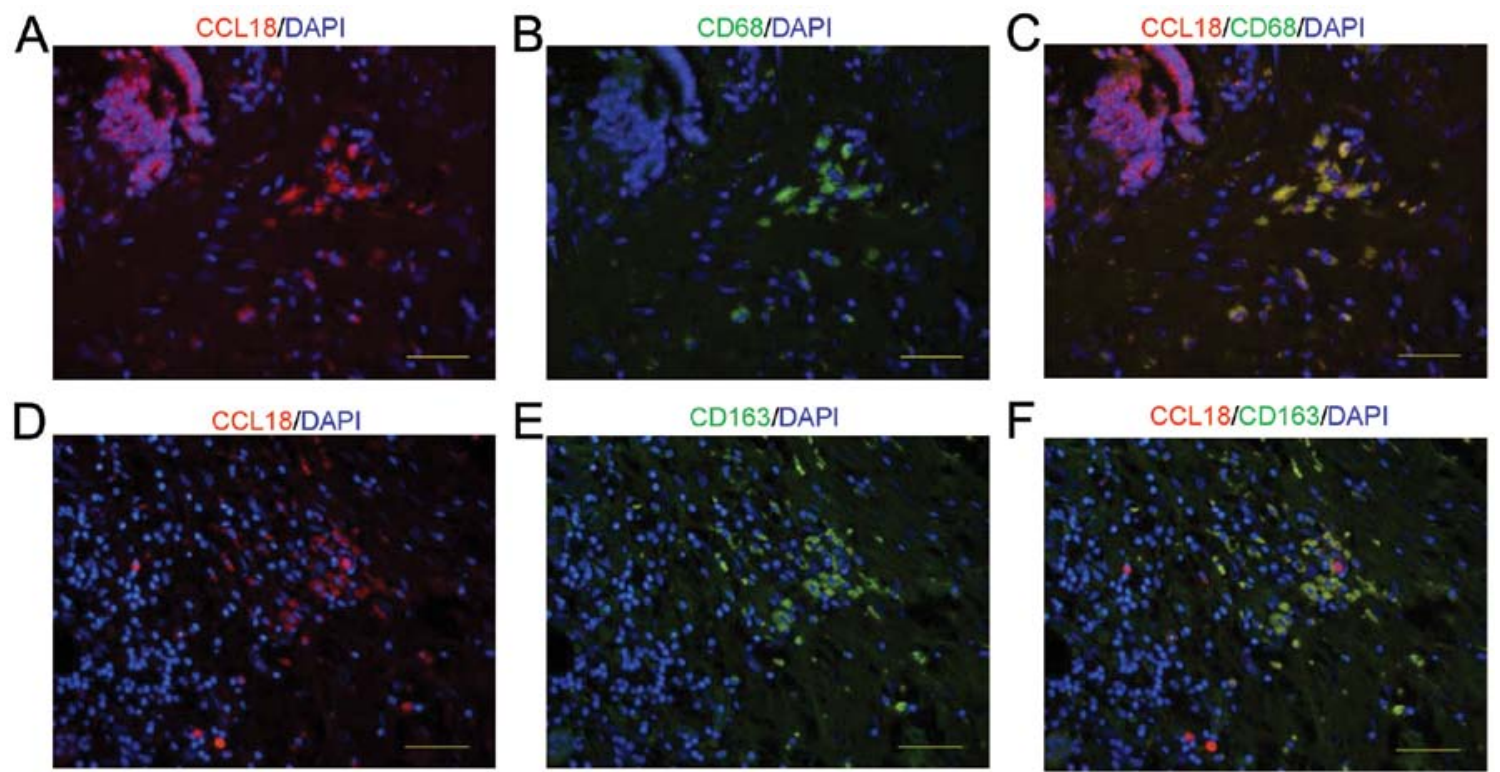

Figure 3. CCL18-positive cells in the mesenchyme of pancreatic cancer tissue are macrophages. Double staining of CCL18 and macrophage specific markers CD68 and CD163 by immunofluorescence. (A-C) Double staining of CCL18 (red) and CD68 (green). (A) CCL18, (B) CD68, (C) Merged image. (D-F) Double staining of CCL18 (red) and CD163 (green). (D) CCL18, (E) CD163, (F) Merged image. Nuclear counterstain with DAPI is blue. Double staining in yellow shows co-localization. Scale bar, $50 \mu \mathrm{m}$.

express limited levels of CCL18. U937 and THP-1 cell lines are representative monocyte/macrophage cells and widely used as human monocyte cells. Macrophage differentiation can be induced in both cell lines by stimulation with PMA 
Table II. Correlation of CCL18 expression with clinical data from PDAC patients.

\begin{tabular}{|c|c|c|c|c|c|c|c|c|c|c|c|c|c|}
\hline \multirow[b]{2}{*}{ Parameters } & \multirow[b]{2}{*}{$\begin{array}{l}\text { No. of } \\
\text { patients }\end{array}$} & \multicolumn{2}{|c|}{$\begin{array}{l}\text { Cancer } \\
\text { cells }\end{array}$} & \multirow[b]{2}{*}{ P-value } & \multicolumn{2}{|c|}{$\begin{array}{l}\text { Mesen- } \\
\text { chymal }\end{array}$} & \multirow[b]{2}{*}{ P-value } & \multicolumn{2}{|c|}{$\begin{array}{c}\text { Mesen- } \\
\text { chymal } \\
\text { positive cell } \\
\text { counts }\end{array}$} & \multirow[b]{2}{*}{ P-value } & \multicolumn{2}{|c|}{$\begin{array}{c}\text { Positive } \\
\text { mesen- } \\
\text { chymal and } \\
\text { cancer cells }\end{array}$} & \multirow[b]{2}{*}{ P-value } \\
\hline & & - & + & & - & + & & $<20$ & $\geq 20$ & & No & Yes & \\
\hline Cases & 62 & 24 & 38 & & 18 & 44 & & 43 & 19 & & 34 & 28 & \\
\hline \multicolumn{14}{|l|}{ Age } \\
\hline$\leq 60$ & 35 & 15 & 20 & 0.309 & 12 & 23 & 0.226 & 25 & 10 & 0.448 & 21 & 14 & 0.251 \\
\hline$>60$ & 27 & 9 & 18 & & 6 & 21 & & 18 & 9 & & 13 & 14 & \\
\hline \multicolumn{14}{|l|}{ Gender } \\
\hline Male & 46 & 18 & 28 & 0.576 & 13 & 33 & 0.528 & 30 & 16 & 0.19 & 26 & 20 & 0.435 \\
\hline Female & 16 & 6 & 10 & & 5 & 11 & & 13 & 3 & & 8 & 8 & \\
\hline \multicolumn{14}{|l|}{ Tumor location } \\
\hline Head & 56 & 22 & 34 & 0.572 & 16 & 40 & 0.567 & 38 & 18 & 0.397 & 3 & 26 & 0.434 \\
\hline Body/tail & 6 & 2 & 4 & & 2 & 4 & & 5 & 1 & & 4 & 2 & \\
\hline \multicolumn{14}{|l|}{ Tumor size } \\
\hline$\leq 2.5 \mathrm{~cm}$ & 16 & 4 & 12 & 0.157 & 6 & 10 & 0.288 & 11 & 5 & 0.592 & 8 & 8 & 0.435 \\
\hline$>2.5 \mathrm{~cm}$ & 46 & 20 & 26 & & 12 & 34 & & 32 & 14 & & 26 & 20 & \\
\hline \multicolumn{14}{|l|}{ Differentiation } \\
\hline Well & 20 & 7 & 13 & 0.449 & 7 & 13 & 0.335 & 16 & 4 & 0.169 & 11 & 9 & 0.602 \\
\hline Moderate/poor & 42 & 17 & 25 & & 11 & 31 & & 27 & 15 & & 23 & 19 & \\
\hline \multicolumn{14}{|l|}{ T stage } \\
\hline $\mathrm{T} 1+\mathrm{T} 2$ & 22 & 12 & 10 & 0.052 & 9 & 13 & 0.109 & 16 & 6 & 0.449 & 15 & 7 & 0.096 \\
\hline $\mathrm{T} 3+\mathrm{T} 4$ & 40 & 12 & 28 & & 9 & 31 & & 27 & 13 & & 19 & 21 & \\
\hline \multicolumn{14}{|l|}{$\begin{array}{l}\text { Lymph node } \\
\text { metastasis }\end{array}$} \\
\hline Negative & 41 & 19 & 22 & 0.072 & 14 & 27 & 0.173 & 31 & 10 & 0.115 & 27 & 14 & 0.015 \\
\hline Positive & 21 & 5 & 16 & & 4 & 17 & & 12 & 9 & & 7 & 14 & \\
\hline \multicolumn{14}{|l|}{ TNM stage } \\
\hline I+IIA & 31 & 15 & 16 & 0.096 & 11 & 20 & 0.201 & 24 & 7 & 0.135 & 21 & 10 & 0.037 \\
\hline $\mathrm{IIB}+\mathrm{III}$ & 31 & 9 & 22 & & 7 & 24 & & 19 & 12 & & 13 & 18 & \\
\hline \multicolumn{14}{|l|}{$\begin{array}{l}\text { Perineural } \\
\text { invasion }\end{array}$} \\
\hline Absent & 52 & 20 & 32 & 0.596 & 16 & 36 & 0.394 & 34 & 18 & 0.117 & 30 & 22 & 0.247 \\
\hline Present & 10 & 4 & 6 & & 2 & 8 & & 9 & 1 & & 4 & 6 & \\
\hline \multicolumn{14}{|l|}{$\begin{array}{l}\text { Vascular } \\
\text { permeation }\end{array}$} \\
\hline Absent & 43 & 17 & 26 & 0.536 & 12 & 31 & 0.497 & 32 & 11 & 0.158 & 23 & 20 & 0.484 \\
\hline Present & 19 & 7 & 12 & & 6 & 13 & & 11 & 8 & & 11 & 8 & \\
\hline \multicolumn{14}{|l|}{ Pre-therapeutic } \\
\hline \multicolumn{14}{|l|}{ CA19-9 level } \\
\hline$<37 \mathrm{U} / \mathrm{ml}$ & 19 & 7 & 12 & 0.536 & 8 & 11 & 0.115 & 13 & 6 & 0.57 & 11 & 8 & 0.484 \\
\hline$\geq 37 \mathrm{U} / \mathrm{ml}$ & 43 & 17 & 26 & & 10 & 33 & & 30 & 13 & & 20 & 23 & \\
\hline
\end{tabular}

$(23,24)$. Previous reports showed that IL4 could stimulate the polarization of peripheral blood monocytes, causing the monocytes to adopt an M2 phenotype and release of high levels of CCL18 (6). We used these two cell lines as monocyte models to verify the expression of CCL18 in monocytes and macrophages. In agreement with previous reports, our results 
Table III. Correlation of CCL18 expression with Ki67, P53, CEA, CA19-9 and CD34 expression in 62 cases of PDAC.

\begin{tabular}{|c|c|c|c|c|c|c|c|c|c|c|c|c|c|}
\hline & \multirow[b]{2}{*}{$\begin{array}{l}\text { No. of } \\
\text { patients }\end{array}$} & \multicolumn{2}{|c|}{$\begin{array}{l}\text { Cancer } \\
\text { cells }\end{array}$} & \multirow[b]{2}{*}{ P-value } & \multicolumn{2}{|c|}{$\begin{array}{l}\text { Mesen- } \\
\text { chymal }\end{array}$} & \multirow[b]{2}{*}{ P-value } & \multicolumn{2}{|c|}{$\begin{array}{l}\text { Mesen- } \\
\text { chymal } \\
\text { positive cell } \\
\text { counts }\end{array}$} & \multirow[b]{2}{*}{ P-value } & \multicolumn{2}{|c|}{$\begin{array}{c}\text { Positive } \\
\text { mesen- } \\
\text { chymal and } \\
\text { cancer cells }\end{array}$} & \multirow[b]{2}{*}{ P-value } \\
\hline & & - & + & & - & + & & $<20$ & $\geq 20$ & & No & Yes & \\
\hline Cases & 62 & 24 & 38 & & 18 & 44 & & 43 & 19 & & 34 & 28 & \\
\hline \multicolumn{14}{|l|}{ Ki67 } \\
\hline Negative & 25 & 13 & 12 & 0.067 & 6 & 19 & 0.336 & 19 & 6 & 0.259 & 15 & 10 & 0.341 \\
\hline Positive & 37 & 11 & 26 & & 12 & 25 & & 24 & 13 & & 19 & 18 & \\
\hline \multicolumn{14}{|l|}{ P53 } \\
\hline Negative & 28 & 12 & 16 & 0.364 & 7 & 21 & 0.363 & 22 & 6 & 0.124 & 16 & 12 & 0.471 \\
\hline Positive & 34 & 12 & 22 & & 11 & 23 & & 21 & 13 & & 18 & 16 & \\
\hline \multicolumn{14}{|l|}{ CEA } \\
\hline Negative & 15 & 7 & 8 & 0.333 & 2 & 13 & 0.110 & 8 & 7 & 0.112 & 8 & 7 & 0.563 \\
\hline Positive & 47 & 17 & 30 & & 16 & 31 & & 35 & 12 & & 26 & 21 & \\
\hline \multicolumn{14}{|l|}{ CA19-9 } \\
\hline Negative & 29 & 11 & 18 & 0.557 & 8 & 21 & 0.519 & 24 & 5 & 0.030 & 14 & 15 & 0.237 \\
\hline Positive & 33 & 13 & 20 & & 10 & 23 & & 19 & 14 & & 20 & 13 & \\
\hline \multicolumn{14}{|l|}{ CD34 } \\
\hline Negative & 48 & 19 & 29 & 0.525 & 13 & 35 & 0.377 & 31 & 17 & 0.117 & 27 & 21 & 0.455 \\
\hline Positive & 14 & 5 & 9 & & 5 & 9 & & 12 & 2 & & 7 & 7 & \\
\hline
\end{tabular}

showed that CCL18 mRNA level (Fig. 4A) and secreted CCL18 protein (Fig. 4E) were low in untreated U937 cells, while both were significantly upregulated after conversion of U937 cells to macrophages by PMA. Impressively, IL4 further dramatically enhanced the CCL18 mRNA level (Fig. 4B) and secretion of CCL18 protein (Fig. 4F) in PMA stimulated U937 cells. We observed no stimulation of CCL18 protein expression in THP-1 cells after PMA treatment (Fig. 4G), but PMA treatment significantly increased the levels of CCL18 mRNA (Fig. 4C). Similar to U937 cells, IL4 significantly upregulated the mRNA level (Fig. 4D) and secretion of CCL18 protein (Fig. 4H) in THP-1 cells stimulated with PMA.

To determine gene and protein expression of CCL18 in pancreatic cancer cells, various pancreatic cancer cell lines (PANC-1, BxPC-3, SW1990 and CAPAN-2) were subjected to qRT-PCR and ELISA analysis of CCL18. All four pancreatic cancer cell lines showed faint CCL18 mRNA expression levels that were similar to those of THP-1 and U937 cells (Fig. 4I). With the exception of the CAPAN-2 cells, which displayed a faintly detectable level of CCL18, the soluble CCL18 protein level in the cell culture supernatant was less than the detection limit of CCL18 ELISA kit (0.2 pg/ml) (Fig. 4J). IL4, which can upregulate the expression of CCL18 in monocyte and macrophage U937 and THP-1 cells, did not induce CCL18 mRNA expression (Fig. 4I) or the soluble CCL18 protein level in cell culture supernatant (Fig. 4J). These results showed that in cultured pancreatic cancer cells, CCL18 was either not expressed or was only expressed at a very low level.
Pancreatic cancer cell lines express the potential CCL18 receptors PITPNM3, CCR6 and GPR3. CCL18 is considered an 'orphan ligand', with its cognate receptor and the underlying pathways unidentified. Recent studies have suggested some potential receptors of CCL18. The study by Catusse et al revealed that CCL18 acts agonistically to and diminishes the CXCR4-mediated effects of CXCL12 via GPR30 (25). Chen et al demonstrated that CCL18 could promote the invasion and migration of breast cancer cells by binding PITPNM3, a membrane-associated phosphatidylinositol transfer domaincontaining protein (6). Zissel et al (26) proposed that the chemokine receptor CCR6 is a CCL18 receptor with the ability to initiate fibroblast activity. We examined the gene expression of these three potential receptors of CCL18 in pancreatic cell lines by qRT-PCR and found that they were expressed at different levels in different cell lines. BxPC-3 cells expressed only PITPNM3, while PANC-1, CAPAN-2 and SW1990 cells expressed various levels of PITPNM3, CCR6 and GPR3 (Fig. 5). These results suggest the possibility of the existence of CCL18 receptors in pancreatic cancer cells and that CCL18 may have effects on the biological behavior of pancreatic cancer cells.

CCL18 promotes migration and invasion of pancreatic cancer cells in vitro, but has no effect on cell proliferation. To investigate whether CCL18 could promote the progression of PDAC, we assessed the cell proliferation, migration and invasion of pancreatic cancer cells by MTT assay, transwell migration 
A

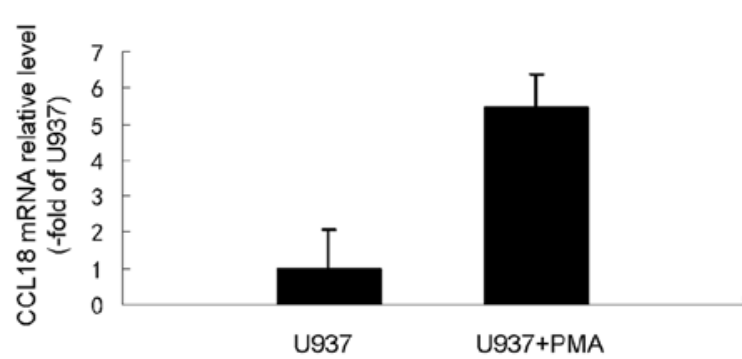

C

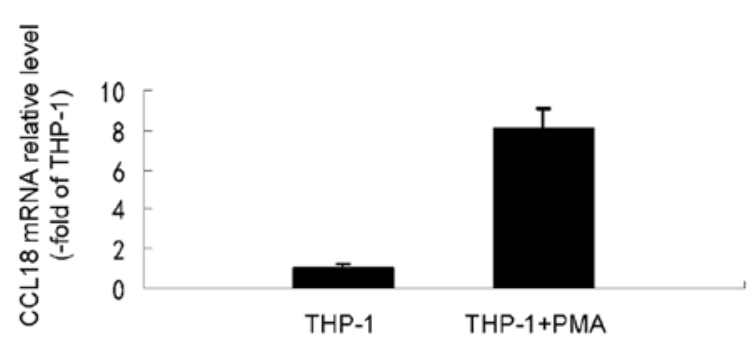

E

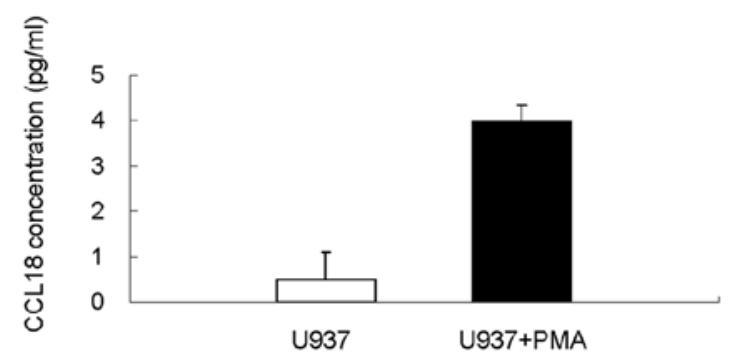

G
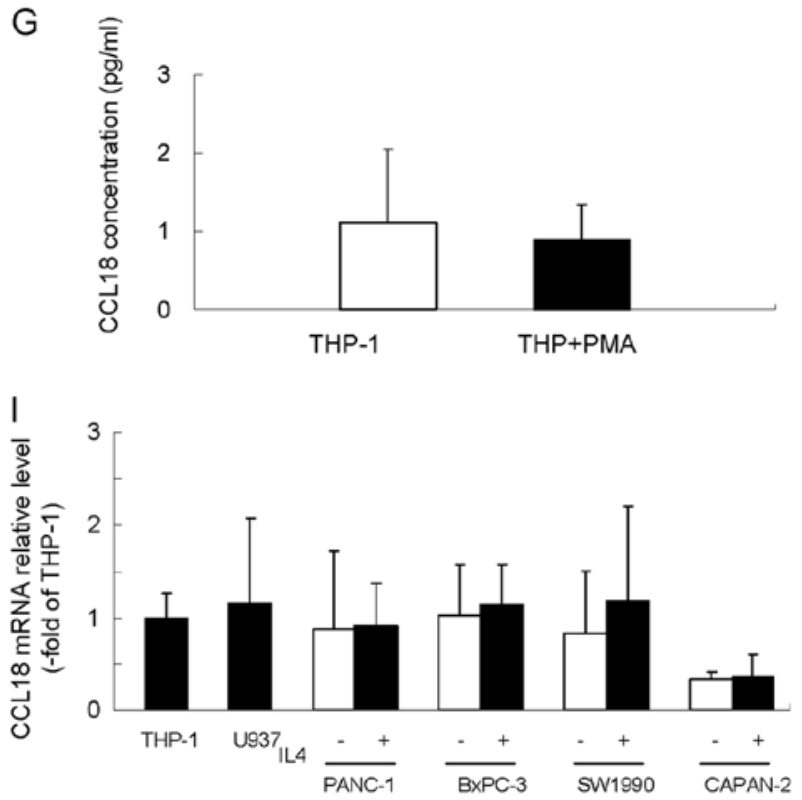

B
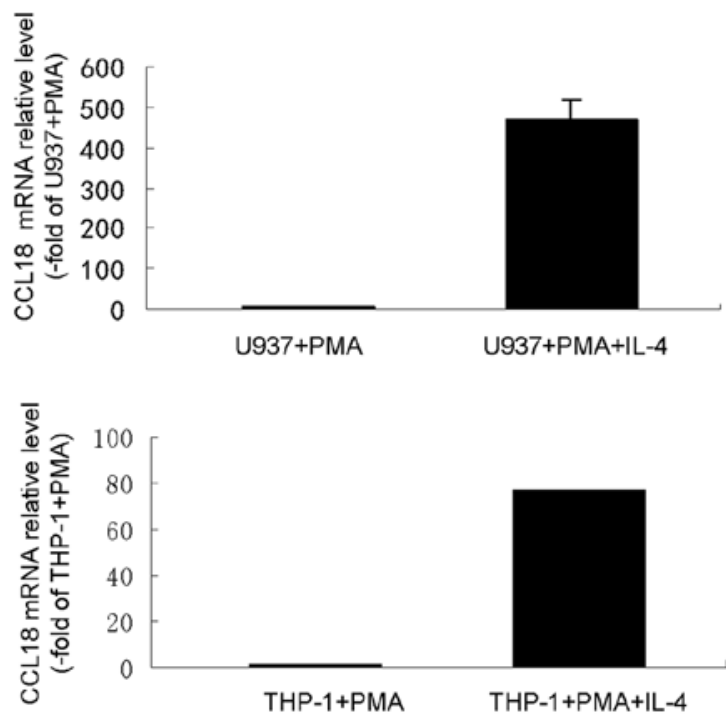

$\mathrm{F}$

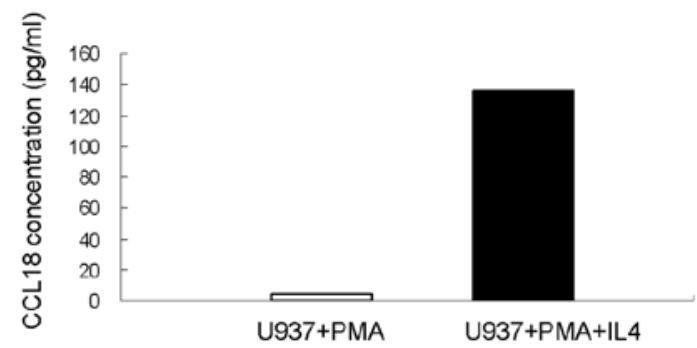

$\mathrm{H}$

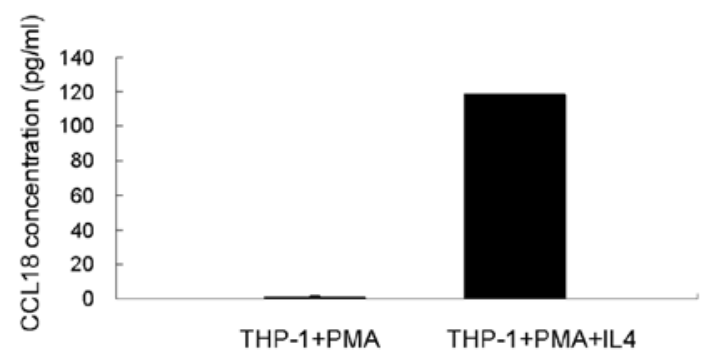

$J$

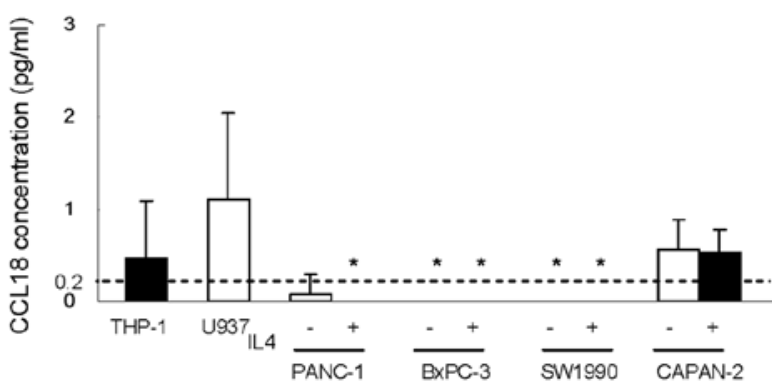

Figure 4. U937 and THP-1 cell derived macrophages secrete high levels of CCL18 while pancreatic cancer cells express limited levels of CCL18. CCL18 mRNA (A-D and I) and protein (E-H and J) expression levels in U937 or THP-1 cell derived monocyte-macrophages and pancreatic cancer cells are shown. *Undetectable.

assay and transwell invasion assay, respectively. MTT assay showed that treatment of pancreatic cancer BxPC-3 (Fig. 6A) and PANC-1 (Fig. 6B) cells with $5 \mathrm{ng} / \mathrm{ml}$ to $25 \mathrm{ng} / \mathrm{ml} \mathrm{rh}-\mathrm{CCL} 18$ for 24,48 and $72 \mathrm{~h}$ did not noticeably alter cell proliferation. In contrast, cell migration after treatment with rh-CCL18 was significantly increased in both BxPC-3 and PANC-1 cells. Migratory capability of BxPC-3 cells was significantly higher after treatment with $10 \mathrm{ng} / \mathrm{ml} \mathrm{rh}-\mathrm{CCL} 18$ in both BxPC-3 cells $(1,191 \pm 141$ versus control $699 \pm 54$ migratory cells/field, $\mathrm{P}=0.0006$, Fig. 6C) and PANC-1 cells $(715 \pm 59$ versus control $383 \pm 66$ migratory cells/ field, $\mathrm{P}<0.0001$, Fig. 6D). Transwell invasion assay revealed that rh-CCL18 significantly increased the number of invading cancer cells compared to serum-free medium in both BxPC-3 (Fig. 6E, P<0.0001) and PANC-1 

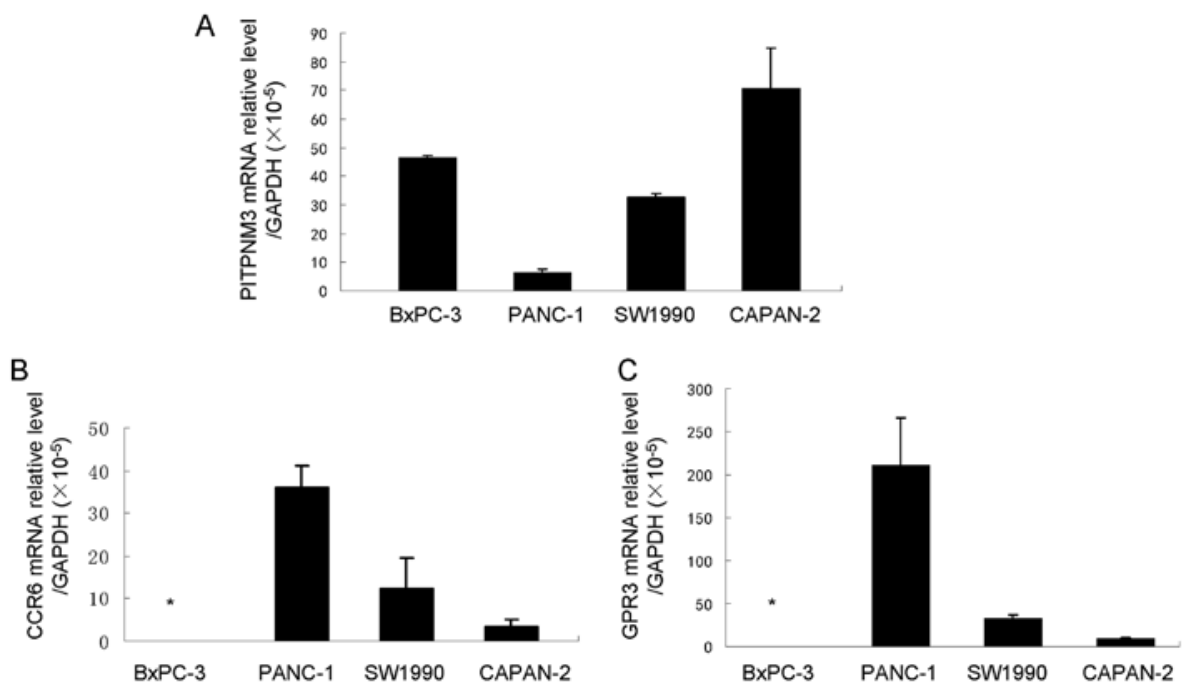

Figure 5. Potential CCL18 receptors are expressed at varying levels in different pancreatic cancer cell lines. The mRNA expression of PITPNM3, CCR6 and GPR3 was determined by qRT-PCR in pancreatic cancer cell lines. (A) PITPNM3; (B) CCR6; (C) GPR3. The expression ratio to GAPDH was calculated. "Undetectable.
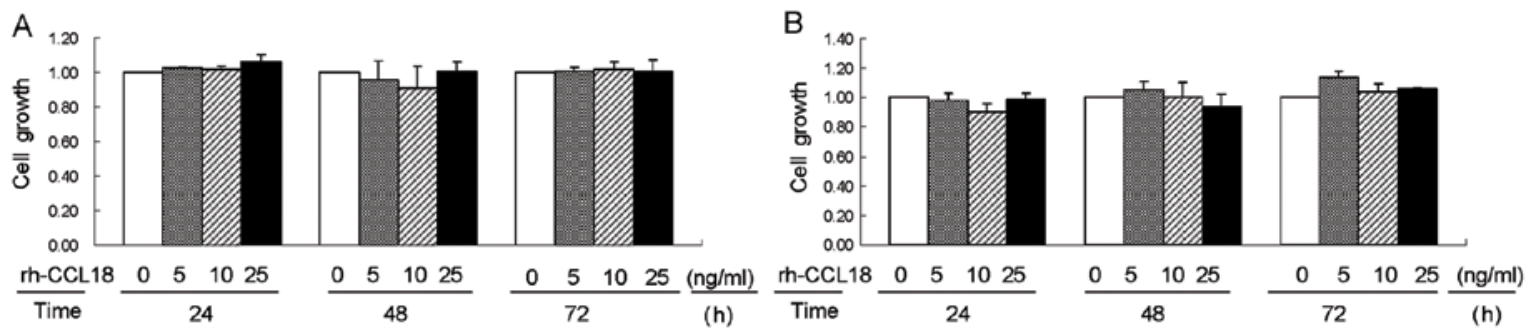

C
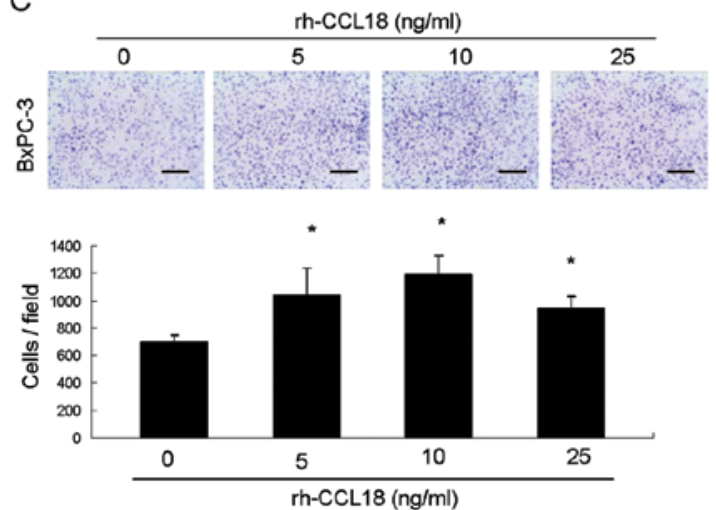

E
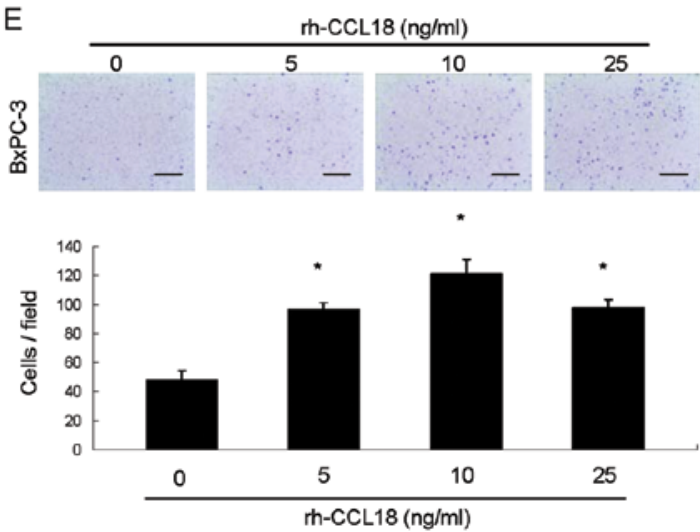

$\mathrm{D}$
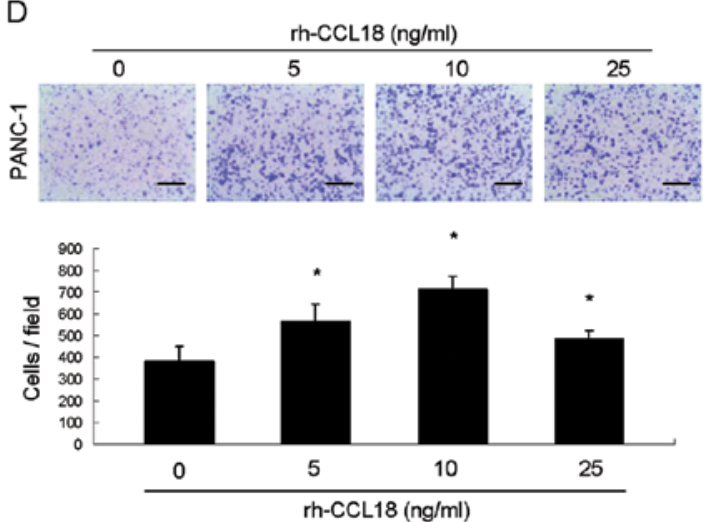

$\mathrm{F}$
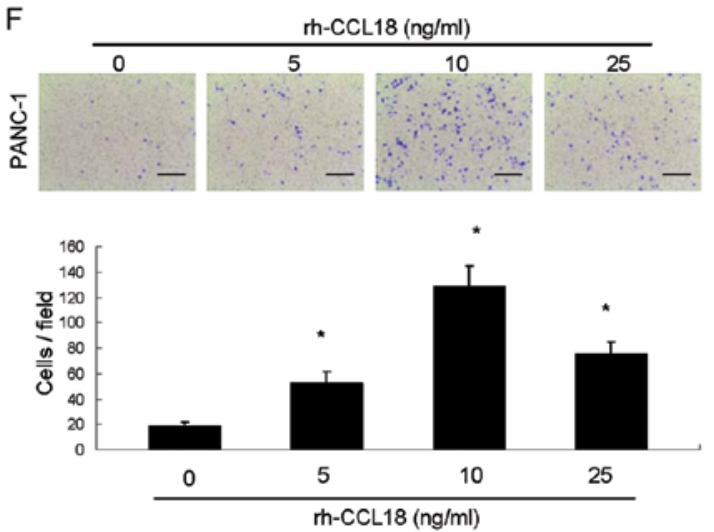

Figure 6. CCL18 promotes migration and invasion but not proliferation of pancreatic cancer cells in vitro. (A and B) The effect of CCL18 on proliferation of pancreatic cancer cells [(A) BxPC-3, (B) PANC-1]. (C-F) The effect of CCL18 on migration (C and D) and invasion (E and F) of pancreatic cancer cells. The migratory or invading cells were counted under a microscope at magnification, $\mathrm{x} 10$ in five random fields per insert assays ("P<0.05 versus control). (C-F) Scale bar, $200 \mu \mathrm{m}$. 

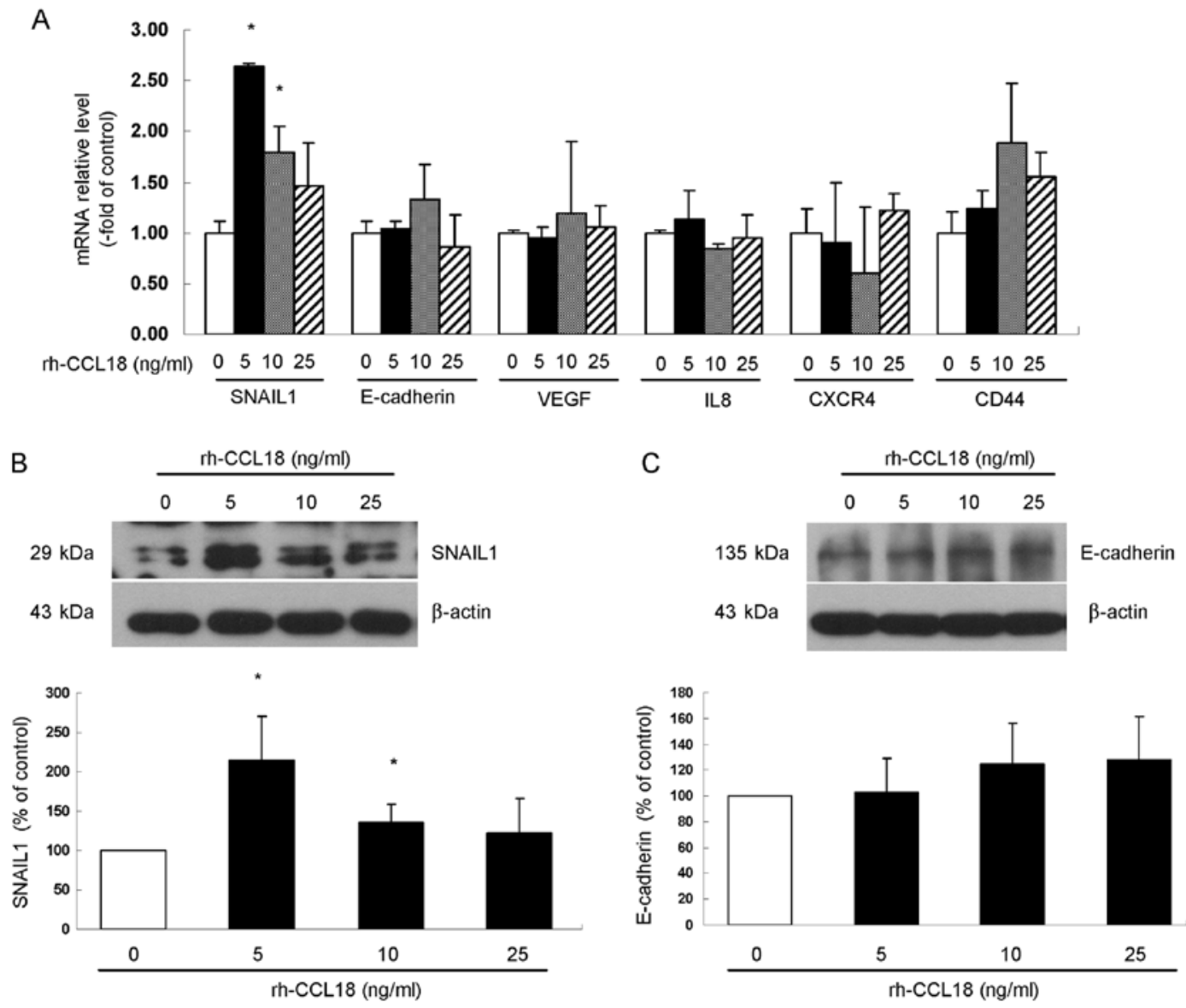

Figure 7. CCL18 promotes the expression of EMT-associated factor SNAIL1. (A) The effect of CCL18 on the mRNA expression of EMT markers, angiogenesis related markers and pancreatic cancer stem cell markers in BxPC-3 cells. (B and C) Effect of CCL18 on the protein expression of EMT related markers SNAIL1 and E-cadherin in BxPC-3 cells ( $\mathrm{P}<0.05$ versus control).

(Fig. 6F, P<0.0001) cells. Invading cancer cells reached their maximum at a dose of $10 \mathrm{ng} / \mathrm{ml} \mathrm{rh}-\mathrm{CCL} 18$. These results indicated that CCL18 was involved in migration and invasion but not proliferation of pancreatic cancer cells.

CXCL16 increased the expression level of EMT-associated factor SNAIL1 in pancreatic cancer cells. To investigate the molecular mechanisms by which CCL18 enhances cell migration and invasion, we examined BxPC-3 cells after stimulation with rh-CCL18 and measured the mRNA expression of EMT-associated factors SNAIL1 and E-cadherin, angiogenesis-associated factors VEGF and IL8 and pancreatic cancer stem cell specific markers CD44 and CXCR4. After $24 \mathrm{~h}$ rh-CCL18 stimulation, gene expression of these factors was examined by qRT-PCR. The results showed that, among all six factors examined, only stimulation with rh-CCL18 significantly upregulated the gene expression of EMT-related factor SNAIL1 at the concentrations of $5 \mathrm{ng} / \mathrm{ml}(2.64 \pm 0.03$-fold of control, $\mathrm{P}=0.020)$ and $10 \mathrm{ng} / \mathrm{ml}(1.79 \pm 0.26$-fold of control, $\mathrm{P}=0.035$ ) (Fig. 7A). Consistent with the increase in SNAIL1 mRNA after stimulation by rh-CCL18 for $24 \mathrm{~h}$, the protein expression of SNAIL1 was upregulated at the concentrations of $5 \mathrm{ng} / \mathrm{ml}(2.14 \pm 0.56$-fold of control, $\mathrm{P}=0.011)$ and $10 \mathrm{ng} / \mathrm{ml}$ (1.35 \pm 0.23 -fold of control, $\mathrm{P}=0.046$ ) (Fig. 7B), while different concentrations of rh-CCL18 treatment for $24 \mathrm{~h}$ did not change the protein level of E-cadherin (Fig. 7C).

\section{Discussion}

In this study, we found that CCL18 was positively expressed in both the epithelial and mesenchymal cells of human PDAC tissues. Moreover, serum CCL18 levels were significantly higher in patients with PDAC in comparison to those of healthy controls. Furthermore, CCL18 expression in cancer epithelial and mesenchymal cells correlated with malignant progression and shorter overall survival of the 62 PDAC patients examined. Most importantly, we observed that treatment with recombinant human CCL18 promoted the migration and invasion of in vitro cultured pancreatic cancer cells.

Chronic inflammation is implicated in a variety of human cancers, including pancreatic cancer $(27,28)$. It is now becoming clear that the tumor microenvironment, which is largely coordinated by inflammatory cells including tumorassociated macrophages (TAM), tumor-associated dendritic cells (TADC) and tumor-infiltrating T cells (TIL), is an indispensable participant in the neoplastic process, proliferation, survival and migration of cancer cells $(29,30)$. As key players in the creation of the tumor-microenvironment, chemokines, which can be produced by the tumor cells and tumor-associated inflammatory cells, may contribute directly to malignant progression $(6,31)$.

CCL18, a vital chemokine in Th-2 immune response, was recently demonstrated to be associated with progression 
of various malignant tumors, including pancreatic cancer (19,32-37). Our immunohistochemistry results revealed that CCL18 was highly expressed in human pancreatic cancer tissues. High CCL18 expression was not restricted to mesenchymal cells, $61.29 \%$ of the cancer tissues examined showed positive CCL18 staining in cancer epithelial cells, although the expression level was relatively weak in contrast to mesenchymal cells (Fig. 1). Furthermore, we demonstrated that CCL18 expression level correlated with the stage of progression and overall survival of PDAC patients (Tables II and III and Fig. 2). These data suggest that CCL18 might contribute to the tumor progression of PDAC in both cancer epithelial and mesenchymal cells.

Using immunofluorescence staining, we found that CCL18-positive mesenchymal cells were CD68 or CD163positive macrophages (Fig. 3). In in vitro cell cultures, we observed that CCL18 was highly expressed in U937 and THP-1 monocytes and macrophages but very low or undetectable in pancreatic cancer PANC-1, BxPC-3, SW1990 and CAPAN-2 cells. In agreement with previous reports, (6) IL4, a stimulator of CCL18 expression, significantly upregulated the expression level of CCL18 in both PMA activated U937 and THP-1 macrophages. In sharp contrast, little to no CCL18 was detected in pancreatic cancer cells, even after stimulation with IL4 (Fig. 4). This result agrees with previous reports showing CCL18 expression under the detection limit and no CCL18 response to conventional stimulators in various carcinoma cells (32). However, the results observed in cultured pancreatic cancer cells were quite different from the immunohistochemistry results we observed using clinical PDAC samples. The discrepancy between the cell culture results and the results observed in the clinical samples is probably due to the distinct differences between the in vivo and in vitro conditions. No CCL18 homologue has yet been found in rodents (16), and the lack of an animal model makes it difficult to confirm the expression of CCL18 in vivo. Nevertheless, the high expression of CCL18 was mainly found in macrophages in the microenvironment of PDAC, implying that macrophages around cancer cells might promote the migration and invasion of pancreatic cancer cells and that CCL18 expression might be essential to this process.

Previous reports showed that overexpression of CCL18 by tumor tissues could promote the invasiveness of cancer cells by interacting with other tumorigenic factors $(6,18)$. Our qRT-PCR results revealed expression of the potential CCL18 receptors PITPNM3, CCR6 and GPR3 in all four of the pancreatic cancer cell lines tested (Fig. 5). Consistently, our in vitro experiments demonstrated that rh-CCL18 promoted the migration and invasion activity of the pancreatic cancer cells BxPC-3 and PANC-1 (Fig. 6). These data suggest that CCL18 may affect the biological behavior of pancreatic cancer cells by binding cell surface receptors.

Finally, we investigated the molecular mechanism by which CCL18 enhanced the progression of pancreatic cancer. Of the six factors we examined, rh-CCL18 upregulated the gene expression of SNAIL1, a marker of EMT, in BxPC-3 cells (Fig. 7A). Increased SNAIL1 expression was confirmed by western blotting (Fig. 7B). Our results were consistent with previous observations that CCL18 or other chemokines are associated with EMT in various tumors $(33,38-40)$. Taken together, these facts suggest that, at least in part, CCL18 promotes the migration and invasion of pancreatic cancer cells through SNAIL1 signaling.

In conclusion, we found that cancer epithelial cells and mesenchymal macrophages from human PDAC tissues positively expressed CCL18. The expression level of CCL18 correlated with tumor progression and the overall survival of PDAC patients. Our findings suggest that serum CCL18 level is a potential biomarker for the diagnosis and prognosis of PDAC, and that CCL18 plays an important role during the tumorigenesis of PDAC.

\section{Acknowledgements}

This study was supported by the Project for Construction of Major Discipline Platform in Universities of Liaoning province, the National Natural Science Foundation of China (no. 81170423), the Science and Technology Program Foundation of Shenyang city, China (no. F13-220-9-01) and the Science and Technology Program Foundation of Liaoning province of China (no. 2011225019).

\section{References}

1. Jemal A, Siegel R, Ward E, Hao Y, Xu J and Thun MJ: Cancer statistics. CA Cancer J Clin 59: 225-249, 2009.

2. Moore MJ: The treatment of advanced pancreatic cancer: current evidence and future challenges. Ann Oncol 19 (Suppl 7): vii304-vii308, 2008.

3. Stathis A and Moore MJ: Advanced pancreatic carcinoma: current reatment and future challenges. Nat Rev Clin Oncol 7: 163-172, 2010.

4. Hamada S, Masamune A and Shimosegawa T: Novel therapeutic strategies targeting tumor-stromal interactions in pancreatic cancer. Front Physiol 4: 331, 2013.

5. Hao NB, Lü MH, Fan YH, Cao YL, Zhang ZR and Yang SM: Macrophages in tumor microenvironments and the progression of tumors. Clin Dev Immunol 2012: 948098, 2012.

6. Chen J, Yao Y, Gong C, et al: CCL18 from tumor-associated macrophages promotes breast cancer metastasis via PITPNM3. Cancer Cell 19: 541-555, 2011.

7. Mantovani A: The chemokine system: redundancy for robust outputs. Immunol Today 20: 254-257, 1999.

8. Zlotnik A and Yoshie O: Chemokines: a new classification system and their role in immunity. Immunity 12: 121-127, 2000.

9. Sallusto F and Mackay CR: Chemoattractants and their receptors in homeostasis and inflammation. Curr Opin Immunol 16: 724-731, 2004.

10. Bromley SK, Mempel TR and Luster AD: Orchestrating the orchestrators: chemokines in control of $\mathrm{T}$ cell traffic. Nat Immunol 9: 970-980, 2008.

11. Strieter RM, Burdick MD, Mestas J, Gomperts B, Keane MP and Belperio JA: Cancer CXC chemokine networks and tumour angiogenesis. Eur J Cancer 42: 768-778, 2006.

12. Ijichi H, Chytil A, Gorska AE, et al: Inhibiting Cxcr2 disrupts tumor-stromal interactions and improves survival in a mouse model of pancreatic ductal adenocarcinoma. J Clin Invest 121: 4106-4117, 2011.

13. Schraufstatter I, Takamori H, Sikora L, Sriramarao P and DiScipio RG: Eosinophils and monocytes produce pulmonary and activation-regulated chemokine, which activates cultured monocytes/macrophages. Am J Physiol Lung Cell Mol Physiol 286: L494-L501, 2004.

14. Sallusto F, Palermo B, Lenig D, Miettinen M, Matikainen S, Julkunen I, Forster R, Burgstahler R, Lipp M and Lanzavecchia A: Distinct patterns and kinetics of chemokine production regulate dendritic cell function. Eur J Immunol 29: 1617-1625, 1999.

15. Pivarcsi A, Gombert M, Dieu-Nosjean MC, et al: CC chemokine ligand 18, an atopic dermatitis-associated and dendritic cellderived chemokine, is regulated by staphylococcal products and allergen exposure. J Immunol 173: 5810-5817, 2004. 
16. Schutyser E, Richmond A and Van Damme J: Involvement of CC chemokine ligand 18 (CCL18) in normal and pathological processes. J Leukoc Biol 78: 14-26, 2005

17. Schraufstatter IU, Zhao M, Khaldoyanidi SK and Discipio RG: The chemokine CCL18 causes maturation of cultured monocytes to macrophages in the M2 spectrum. Immunology 135: 287-298, 2012.

18. Zhang B, Yin C, Li H, et al: Nirl promotes invasion of breast cancer cells by binding to chemokine (C-C motif) ligand 18 through the PI3K/Akt/GSK3 $\beta /$ Snail signalling pathway. Eur J Cancer 49: 3900-3913, 2013.

19. Li D, Duell EJ, Yu K, et al: Pathway analysis of genome-wide association study data highlights pancreatic development genes as susceptibility factors for pancreatic cancer. Carcinogenesis 33 1384-1390, 2012

20. Sobin LH, Gospodarowicz MK and Wittekind CH (eds): International Union Against Cancer (UICC) TNM Classification of Malignant Tumors. 7th edition. Wiley-Blackwell, Oxford, 2009.

21. Ni XG, Bai XF, Mao YL, et al: The clinical value of serum CEA, CA19-9, and CA242 in the diagnosis and prognosis of pancreatic cancer. Eur J Surg Oncol 31: 164-169, 2005.

22. Yasue M, Sakamoto J, Teramukai S, Morimoto T, Yasui K, Kuno N, Kurimoto K and Ohashi Y: Prognostic values of preoperative and postoperative CEA and CA19.9 levels in pancreatic cancer. Pancreas 9: 735-740, 1994.

23. Harris P and Ralph P: Human leukemic models of myelomonocytic development: a review of the HL-60 and U937 cell lines. J Leukoc Biol 37: 407-422, 1985.

24. Daigneault M, Preston JA, Marriott HM, Whyte MK and Dockrell DH: The identification of markers of macrophage differentiation in PMA-stimulated THP-1 cells and monocytederived macrophages. PLoS One 5: e8668, 2010.

25. Catusse J, Wollner S, Leick M, Schröttner P, Schraufstätter I and Burger M: Attenuation of CXCR4 responses by CCL18 in acute lymphocytic leukemia B cells. J Cell Physiol 225: 792-800, 2010.

26. Zissel Gl, Höhne K, Kilic A, Maier C, Goldmann T, Prasse A, Ploenes T, Trepel M, Eibel $\mathrm{H}$ and Müller-Quernheim J: Identification of the CCL18 receptor - effects of CCL18 on human lung fibroblasts in pulmonary fibrosis are mediated via CCR6. Pneumologie 66: P3_012, 2012.

27. Balkwill F, Charles KA and Mantovani A: Smoldering and polarized inflammation in the initiation and promotion of malignant disease. Cancer Cell 7: 211-217, 2005.

28. Guerra C, Collado M, Navas C, Schuhmacher AJ, HernándezPorras I, Cañamero M, Rodriguez-Justo M, Serrano M and Barbacid M: Pancreatitis-induced inflammation contributes to pancreatic cancer by inhibiting oncogene-induced senescence. Cancer Cell 19: 728-739, 2011.
29. Coussens LM and Werb Z: Inflammation and cancer. Nature 420: 860-867, 2002.

30. Balkwill F, Mantovani A: Inflammation and cancer: back to Virchow? Lancet 357: 539-545, 2001.

31. Darash-Yahana M, Gillespie JW, Hewitt SM, et al: The chemokine CXCL16 and its receptor, CXCR6, as markers and promoters of inflammation-associated cancers. PLoS One 4: e6695, 2009

32. Schutyser E, Struyf S, Proost P, et al: Identification of biologically active chemokine isoforms from ascitic fluid and elevated levels of CCL18/pulmonary and activation-regulated chemokine in ovarian carcinoma. J Biol Chem 277: 2458424593, 2002.

33. Ploenes T, Scholtes B, Krohn A, Burger M, Passlick B, MüllerQuernheim J and Zissel G: CC-chemokine ligand 18 induces epithelial to mesenchymal transition in lung cancer A549 cells and elevates the invasive potential. PLoS One 8: e53068, 2013.

34. Günther C, Zimmermann N, Berndt N, Grosser M, Stein A, Koch A and Meurer M: Up-regulation of the chemokine CCL18 by macrophages is a potential immunomodulatory pathway in cutaneous T-cell lymphoma. Am J Pathol 179: 1434-1442, 2011.

35. Plönes T, Krohn A, Burger M, Veelken H, Passlick B, MüllerQuernheim J and Zissel G: Serum level of CC-chemokine ligand 18 is increased in patients with non-small-cell lung cancer and correlates with survival time in adenocarcinomas. PLoS One 7: e41746, 2012.

36. Urquidi V, Kim J, Chang M, Dai Y, Rosser CJ and Goodison S: CCL18 in a multiplex urine-based assay for the detection of bladder cancer. PLoS One 7: e37797, 2012.

37. Leung SY, Yuen ST, Chu KM, Mathy JA, Li R, Chan AS, Law S, Wong J, Chen X and So S: Expression profiling identifies chemokine (C-C motif) ligand 18 as an independent prognostic indicator in gastric cancer. Gastroenterology 127: 457-469, 2004.

38. Fanelli MF, Chinen LT, Begnami MD, Costa WL Jr, Fregnami JH, Soares FA and Montagnini AL: The influence of transforming growth factor- $\alpha$, cyclooxygenase- 2 , matrix metalloproteinase (MMP)-7, MMP-9 and CXCR4 proteins involved in epithelialmesenchymal transition on overall survival of patients with gastric cancer. Histopathology 61: 153-161, 2012.

39. Hao M, Zheng J, Hou K, Wang J, Chen X, Lu X, Bo J, Xu C, Shen K and Wang J: Role of chemokine receptor CXCR7 in bladder cancer progression. Biochem Pharmacol 84: 204-214, 2012.

40. Bertran E, Caja L, Navarro E, Sancho P, Mainez J, Murillo MM, Vinyals A, Fabra A and Fabregat I: Role of CXCR4/SDF-1 alpha in the migratory phenotype of hepatoma cells that have undergone epithelial-mesenchymal transition in response to the transforming growth factor-beta. Cell Signal 21: 1595-606, 2009. 